\title{
SCIENCE AND DEMOCRACY \\ " Epistemological Study "
}

\begin{abstract}
Dr. Khaled Ahmed Qutb*
ABSTRACT

Philosophers of science have raised many questions about the relationship between science and democracy: Does the science work on the development of democratic values within modern societies, for example wealth and security, although the products of science and its applications sometimes cause risk to these communities? Dose the science make the politics more rational, or it sometimes contributes to make the politics irrational to serve the purposes of specific political ideology? Can we apply what we called the "Social Contract for Science" in order to make science separating from any political or religious institutions?
\end{abstract}

* Ass. Prof. of Philosophy Science, Faculty of Arts, Al-Fayoum University.

$-1-$ 
Philosophers of science has raised some questions about the interrelationship between science, knowledge and non-scientific institutions (political, social, religious) in an attempt to distinguish between science that serves the political, social and religious interests and the science that addresses the issues of public interest, in other words, an attempt to differentiate between science-based funding in order to obtain results that serve the interests of specific political, economic and science seeking scientific knowledge itself, we have found many other images of funding adopted by medical institutions for research to serve political purposes, as we also find significant financial support from religious institutions to support research showing the relationship between science and religion such as searching, for example, the physiological basis of religious beliefs, and feelings of negative/ painful resulting from lack of faith. Perhaps the most important questions raised by recent philosophers of science is the relationship between science and democracy.

Philip Kitcher is one of the contemporary philosophers of science who refuses the authoritarian way in science which imposes absolute standard through means seems democratic, therefore, Kitcher argues that "the ordered science" can help us to make collective decisions by the members of the community not by the scientists or scholars only. Kitcher, also reveals the role of social dimensions of scientific knowledge in terms of the impact of social practices on the values of truth and institutionalization of these values, Kitcher uses in his philosophy of science the concept of social epistemology which means putting all the theories and methodologies into account without the authority of scientists, the progress of science enhanced by the practice of consensus within the community. 
